\title{
Effect of cut seed tubers and pre-germination on potato tuber yield
}

\author{
Pape DIOP*, Elhadji Serigne SYLLA, Mamadou DIATTE, Babacar LABOU and \\ Karamoko DIARRA
}

\author{
UCAD, Equipe Production et Protection Intégrées en Agro écosystèmes Horticoles - 2PIA, \\ Faculté des Sciences et Techniques, Dakar, Sénégal. \\ * Corresponding author; E-mail:diopape@yahoo.fr; Tel: +221776173472
}

\begin{abstract}
Potato (Solanum tuberosum L.) is one of the important vegetable crops in Senegal with the potential to improve the national food supply and economic benefits to smallholder producers. Experiment was conducted from November 2015 to March 2016 to assess the impact of cut seed tubers and pre-germination on seed tuber storage conditions on potato tubers yield. Four treatments were used for experiment. Pre-plant seed treatments were (T1) 136 whole seed tubers 45-55 g then pre-germinated; (T2) 68 cutted tubers 22-28 g then pregerminated; (T3) 68 pre-germinated seed tubers then cut 22-28 g; (T) 136 whole seed tubers 45-55 g not pregerminated (maintained $4{ }^{\circ} \mathrm{C}$ ). Plants grown from whole and pre-germinated seed tubers had significantly higher yield and more number of secondary stems per plant, when compared to cut and or no pre-germinated seed $(\mathrm{P}<0.001)$. Daughter tubers produced from cut seed resulted in higher small size potato tubers than those from whole seed $(\mathrm{P}<0.001)$. However, no significant difference was found on potato seed emergence. Our results indicated a clear advantage to plant whole and pre-germinated seed potatoes with the aim of producing healthier daughter tubers and increasing yields.
\end{abstract}

(C) 2019 International Formulae Group. All rights reserved.

Keywords: Seed potato, whole seed, pre-germination, Niayes, Senegal.

\section{INTRODUCTION}

Potato (Solanum tuberosum L.) is now the first most important vegetable produced in the world. In Senegal, potatoes are considered as an important economically vegetable crop because of their high nutritional value, high cash crop value. The crop is grown in an area of 5284 hectares with a total production of 118783 tons per year (FAO, 2017). Local potato production in Senegal decreased considerably from year to year while importation of table potatoes has increased (Cromme et al., 2010). Each year, more than 80000 tones come mainly from Europe (Belgium, France, Germany, Holland, etc.)
(Fao stat, 2017). The decline of potato cultivation in Senegal is mainly due to pests, but also to the effect of some cultural practices, including potato tubers pregerminated or not and whole or cut tubers seeding.

Pre-germination can influence physiological age of seed tubers. Seeds stored cold $\left(4-5{ }^{\circ} \mathrm{C}\right)$ should not be directly grounded. Seed potatoes age over time and this process accelerates when seed is exposed to higher temperatures (Blauer et al., 2013). Knowles and Knowles (2006) propose that tubers pregerminated at high temperatures might lead to increased physiological age of the tubers and 
therefore-increases stem numbers per plant. It has been shown that the number of stems per plant can be used as an early season predictor of potato yield and size (Nepal et al., 2016).

Cutting seed has been adopted in Senegal because of the lack of adequate availability of seedlings whole seed but also by reducing the seed cost. However, cut surface may be susceptible to attack by soilborne fungi, particularly during the cool and wet conditions. Whole seed tubers of potato (S. tuberosum L.) have been reported to have some performance advantages over seed pieces produced by cutting whole tubers, even if the cut seed is treated with a fungicide dust (Kawakami et al., 2003). Research and commercial production history have shown that potato seed piece (>50 g) may influence plant development and yield (Khurana and Pandita, 1982; Strange and Blackmore, 1990). For example, Arsenault and Christie (2004) showed that tuber yield could be related to the number of main stems irrespective of seed size, considerable data have accumulated which support the use of stems as the unit of density in the potato crop. However, other reports have shown that the total yield of many cultivars is not substantially affected by seed piece (Nolte et al., 2003). The use of whole or cut seed to maximize yield potential may depend on the cultivar and production environment. Nelson and Thoreson (1982), obtained higher total yield in cv. Norgold Russet by using seed pieces cut from mother tuber. The objective of the current work investigated the performance of whole seed compared to cut seed tubers and the effects of pre-germination on seed tuber storage conditions on potato tubers yield.

\section{MATERIALS AND METHODS \\ Experimental site}

The experiment was conducted in National Agency for Integration and Agricultural Development farm (ANIDA), Dakar, Senegal. The experimental site is located in main vegetable-producing area "Niayes", in Senegal at $14^{\circ} 46^{\prime} 52^{\prime \prime}$ N, $17^{\circ} 13^{\prime}$ $40^{\prime \prime} \mathrm{W}$ co-ordinates. This area is characterized by a short rainy season (July-September, 400 $500 \mathrm{~mm}$ rainfall) and a long dry season
(October-June) during which most potato crops are grown under irrigation.

\section{Pre-germination treatments}

Commercially grown Florice seed tubers were purchased by the research station of the Northern committee in France. The cv. Florice potato variety is widely grown throughout West Africa including Mali, Côte d'Ivoire, Benin, and Senegal for the fresh and processing markets. Florice has a high early yield and is approximately 15 days earlier than Spunta. The variety has a short dormancy, which makes it suitable for two plantings shortly after each other. Florice is suitable for warmer climates with short growing periods. For pre-germination, tubers were placed in a lighted room away from the sun. First we put sand well spread and then watered. Seeds tubers are placed on the ground and covered with well-sown potato sacks. The sprouted tubers were checked every 48 hours until two weeks. Pre-plant seed treatments were (T1) 136 whole seed tubers 45-55 g then pre-germinated; (T2) 68 cut seed tubers $22-28 \mathrm{~g}$ then pre-germinated; (T3) 68 pre-germinated seed tubers then cut 22-28 g; (T) 136 whole seed tubers 45-55 g not pre-germinated (maintained $4{ }^{\circ} \mathrm{C}$ ). For each treatment, thirty six seeds were sown. Compost was used as the germination medium. The experiments were carried out between November 2015 to March 2016.

All experiments received 40 of NPK soluble fertilizer (15-10-30). Paraquat/ monolaurin herbicides were applied to all experiments and gave excellent weed control. Organic manure (Italpollina) was added at a dose of $2 \mathrm{~kg} / 10 \mathrm{~m}^{2}$. Spraying with thiocarbamate and tin-based fungicides against potato blight was routine in all experiments and the disease did not affect any experiment. All experiments were harvested after complete senescence.

\section{Experimental design}

The experiment was carried out in randomized complete block design (RCBD) with four (4) treatments and four (4) replications. Each block was dimensioned of $11 \mathrm{~m}$ on $5 \mathrm{~m}$ and separated. Data collected included the tuber emergence time, number of 
germinated seeds, proportion of small sized potato tubers $<50 \mathrm{~mm}$; proportion of plants with secondary stems, total yield and net yield (t/ha). Total yield was determined by calculating the total of all categories combined and market yield was determined by calculating the total of all categories except small sized potato tubers $<50 \mathrm{~mm}$ and rotten potato tubers.

\section{Statistical analyses}

Analyses were performed with the $\mathrm{R}$ software version 3.4.1 (R. Core Team, 2016). Proportion of small sized potato tubers $<50$ $\mathrm{mm}$ and proportion of plants with secondary stems were analyzed using a GLM, based on a binomial distribution and a logit link function. Total and net potato yield were analyzed using a generalized linear model (GLM), based on a Gaussian distribution and an identity link function. Models were fitted by maximum likelihood (ML) and their suitability was assessed by checking normality and randomness of residuals. Multiple comparisons of means were done using Tukey contrasts $(\mathrm{P}<0.05)$.

\section{RESULTS}

\section{Rate and speed of seedling potato emergence}

Rate of seedling potato emergence was almost total in treatments $\mathrm{T} 1, \mathrm{~T} 2$ and $\mathrm{T} 3$ with percentage respectively $97.05 \%, 100 \%$ and $97.67 \%$ at the second week. However, it was $65.36 \%$ in treatment $\mathrm{T}$. Whole or cut and pregerminated tubers have the same germination speed compared to no pre-germinated seed. At the third week, $100 \%$ emergence was obtained in all treatments (Table 1).

\section{Plants with secondary stems}

Mean proportion of plants with secondary stems was significantly different between treatments $\left(\chi^{2}=78.11 ; \mathrm{df}=3 ; \mathrm{P}<\right.$ 0.001). The proportion of plants with secondary stems was very higher in pregerminated and whole seed treatment (T1) with a percentage of $86.16 \%$. It was followed by the cut and pre-germinated tubers treatment (T2) with percentage of $43.82 \%$. Fewer proportions of plants with secondary stems were noted on no pre-germinate and whole tubers $(\mathrm{T})$ and with cut and pregerminate tubers (T3); (Figure 3).

\section{Small size potato tubers}

Results showed that cut seeds had a significant effect on yield small size tubers < $50 \mathrm{~mm}$ in diameter $\left(\chi^{2}=78.11 ; \mathrm{df}=3 ; \mathrm{P}=0.023\right)$. The whole seed ( $\mathrm{T}$ and $\mathrm{T} 1)$ produced significantly fewer proportion of small size tubers $<50 \mathrm{~mm}$ than cut seed tubers (T2 and T3). No effect of pre-germinated seed treatments was noted on the small size seed yield (Figure 2).

\section{Total and net yield}

Both, total and net yield were significantly higher among pre-germinate and whole seed treatment (T1) when compared to all other treatments $(\mathrm{T}, \mathrm{T} 2, \mathrm{~T} 3)$ respectively $\left(\chi^{2}=109.5 ; \mathrm{df}=3 ; \mathrm{P}<0.001\right),\left(\chi^{2}=137.56 ; \mathrm{df}=3\right.$; $\mathrm{P}<0.001)$. Mean total yield for T, T1, T2 and $\mathrm{T} 3$ were $10.875,16.875,12.625$ and 10.125 t/ha respectively. Mean net total yield for $\mathrm{T}$, $\mathrm{T} 1, \mathrm{~T} 2$ and $\mathrm{T} 3$ were $7.5 ; 14.25 ; 7.625$ and 7.125 t/ha respectively (Figure 3).

Tab1e 1: Effect of whole, cut seed tubers and pre-germination on germination percentage (\%), and speed of seedling potato emergence.

\begin{tabular}{ccccc}
\hline Weeks & \multicolumn{4}{c}{ Treatments } \\
\cline { 2 - 5 } & $\begin{array}{c}\text { T: Whole } \\
\text { tubers }\end{array}$ & $\begin{array}{c}\text { T1: Whole tubers+ } \\
\text { Pre-germination }\end{array}$ & $\begin{array}{c}\text { T2: Cut tubers+ } \\
\text { Pre-germination }\end{array}$ & $\begin{array}{c}\text { T3: Pre-germination+ } \\
\text { cut tubers }\end{array}$ \\
\hline W1 & 0 & 14,66 & 43,61 & 28,75 \\
W2 & 65,36 & 97,05 & 100 & 97,67 \\
W3 & 100 & 100 & 100 & 100 \\
\hline
\end{tabular}




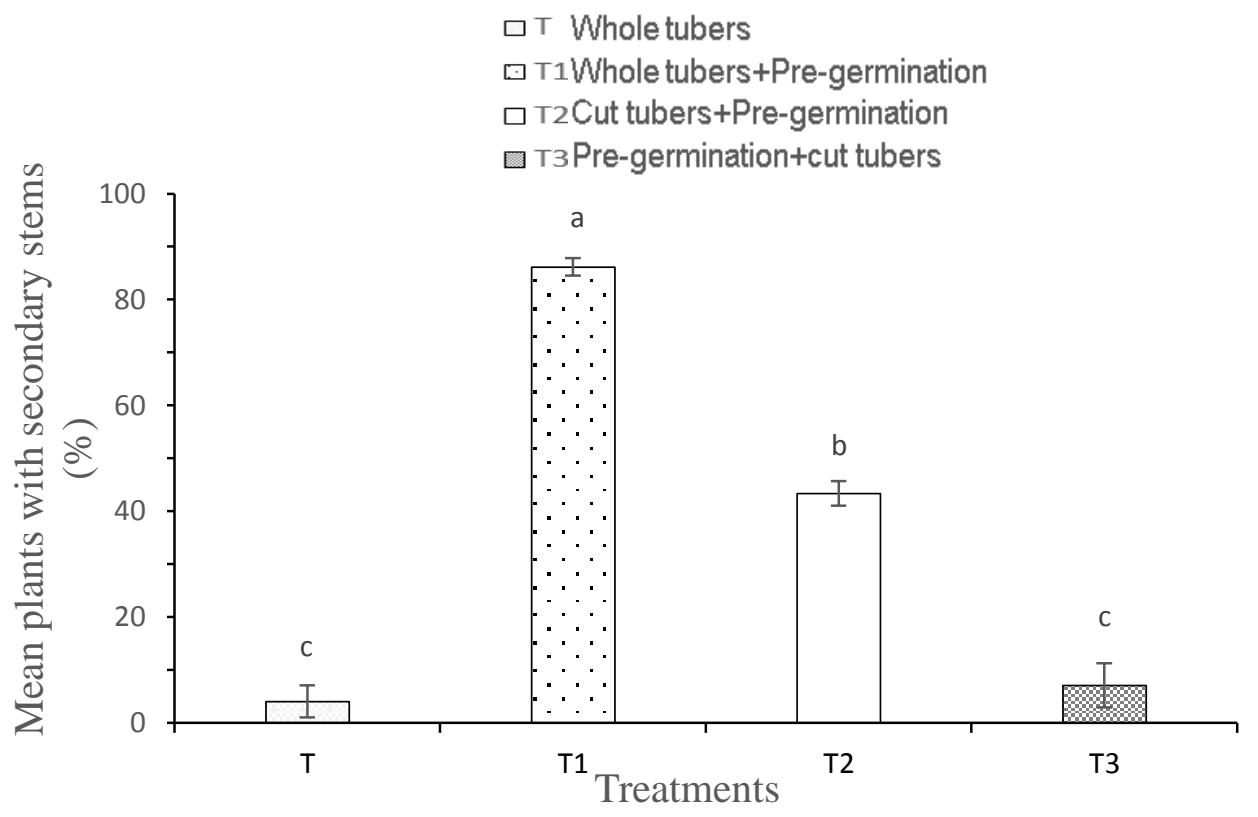

Figure 1: Effect of whole, cut seed tubers and pre-germination, mean percentage of small size potato tubers $<50 \mathrm{~mm}$. Bars topped by same letter are not statistically different $(\mathrm{P}<0.05)$.

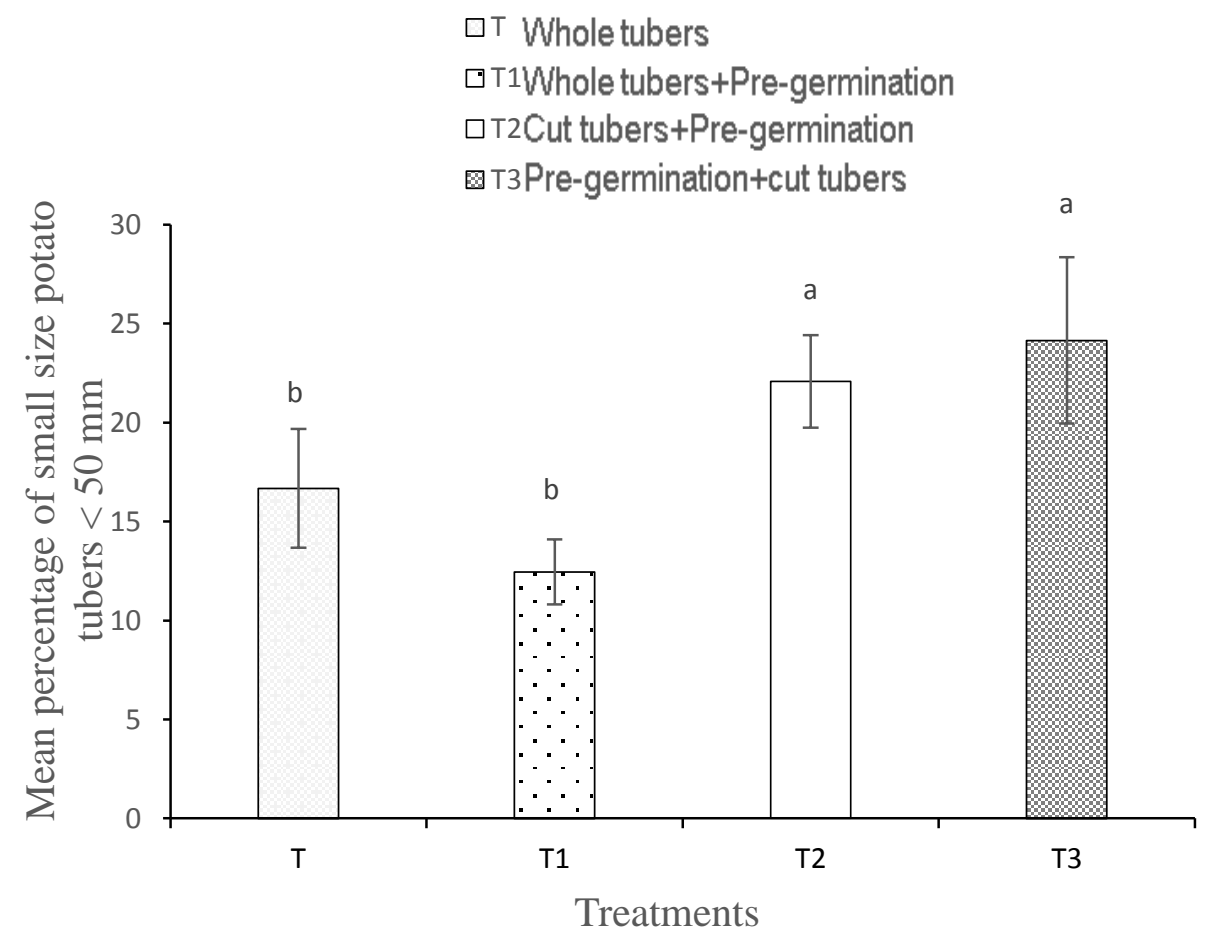

Figure 2: Effect of whole, cut seed tubers and pre-germination on plants with secondary stems (\%). Bars topped by same letter are not statistically different $(\mathrm{P}<0.05)$. 


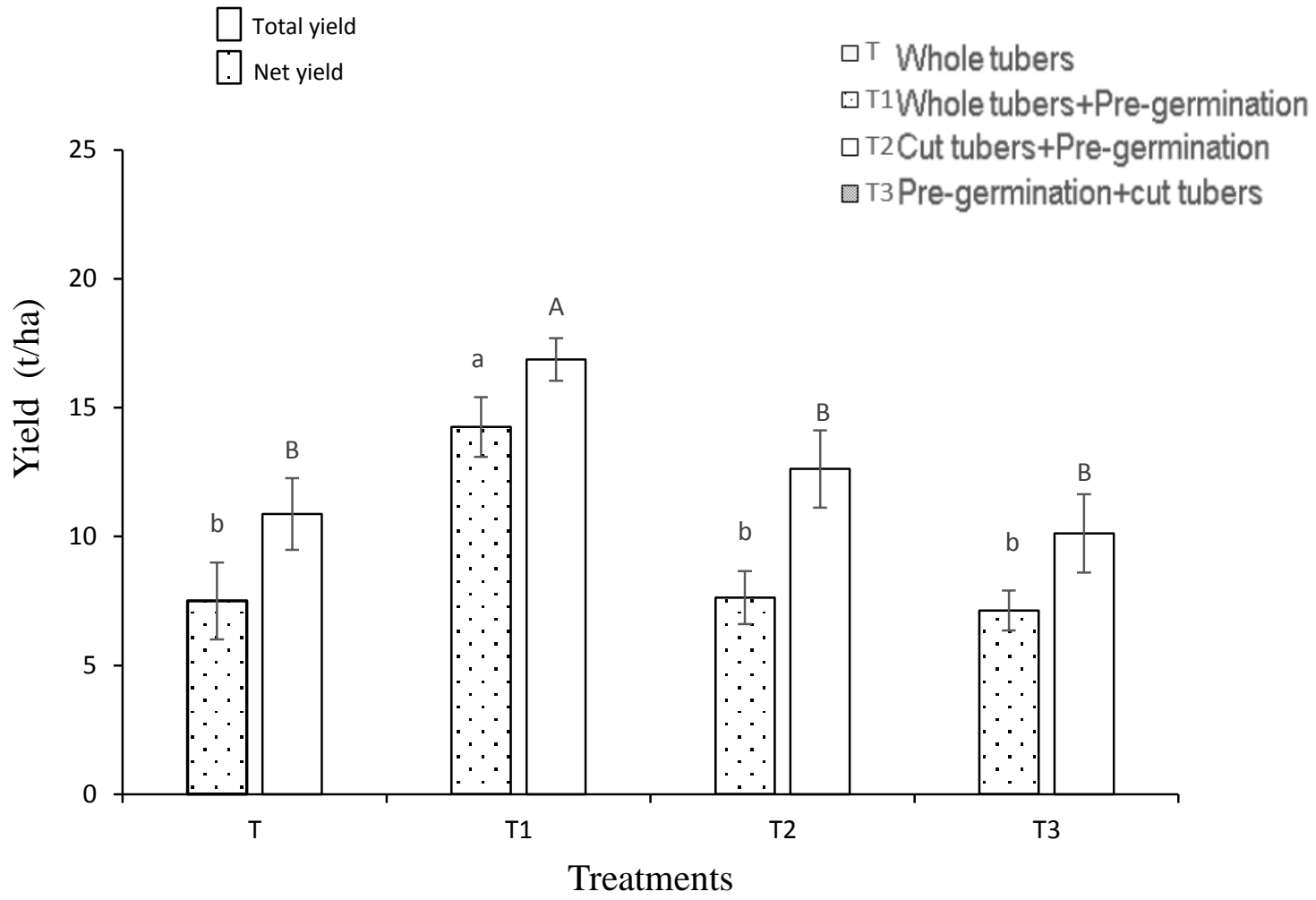

Figure 3: Effect of whole, cut seed tubers and pre-germination on total and net potato tuber yield (t/ha). Bars topped by same letter are not statistically different $(\mathrm{P}<0.05)$.

\section{DISCUSSION}

Our experiments provided information on the impact of seed type (cut versus whole) and seed pre-germination on resulting tuber potato yield under vegetable-producing area "Niayes" conditions. Results revealed that the pre-germinated seed potatoes have a significant influence on speed of seedling potato emergence. However, no significant difference was found on potato seed emergence. We showed also that cutting and no pre-germinated seed decreased the number of secondary stems per plant. Potato tubers yields produced from cut seed had higher small size potato tubers than those produced from whole seed. Cutting and/or no pregerminated seeds had an impact on yield. Whole and pre-germinated seed potatoes produced a greater amount of daughter tubers than cut and/or no pre-germinated.

This study hypothesis that pregermination and planting of whole tubers would increase potato yields. Our results showed more vigorous plants (Figure1) and better yields (Figure 3) with whole and pregerminated tubers (T1) than whole tubers $(\mathrm{T})$ and cut and pre-germinated tubers seeds (T2,T3). According to Nolte et al. (2003), whole seed potatoes had greater vigor than cut seed, since the cut seeds need to increase their metabolic activity in developing a new suberin and phylum barrier. Previous works suggest that seed type and weight are important determinants of plant development and yield (Adhikari, 2005; Webster et al., 2018). Planting large seed is reported to result in higher number of tubers per plant and higher total tuber yields than from planting smaller seed (Arioglu, 2009; Masarirambi et al., 2012). This yield result could be explained by a better plant vigor noted at whole and pregerminated tubers compared to the other treatments. In fact, this better vigor of the plants obtained from whole and pre- 
germinated tubers could be due to the combined effect of whole tubers and the pregermination of tubers before planting. However, work has shown similar results in yield by planting only whole or pregerminated tubers. Low tuber yields from cutting seedling tubers may well be explained by low stem production, poor foliage development, and thus a low capacity for assimilate production explain by Engels et al. (1993). On the other hand, yield can be decreased by planting directly from $4.4{ }^{\circ} \mathrm{C}$ storage resulted in significantly fewer stems per plant compared to pre-germinated seed (Arsenault and Christie, 2004).

In this study, the size of whole seed had significant effect on the yield of tubers < $50 \mathrm{~mm}$ (Figure 2). The whole seed ( $\mathrm{T}$ and $\mathrm{T} 1$ ) produced significantly fewer proportions of small size tubers $<50 \mathrm{~mm}$ than cut seed tubers (T2 and T3). It seems that cutting the tubers would increase tuber yield. According to Kabir et al. (2004), the whole tubers seeds gave significantly higher yields than cut pieces. Cut seeds related to their lack of protective layer were more vulnerable to pathogens than whole seeds. This reasoning is supported by previous work which showed that there was no difference between whole seed and cut seed on progeny yield and disease incidence when cut seed were treated with fungicides (Nolte et al., 2003; Kumar et al., 2015). Seed rate comes out to be low by planting small tubers or by using cut seed pieces, besides increased average tuber weight and the highest number (10.23) and weight of tubers/hill $(0.40 \mathrm{~kg})$ were observed in T6 large size-whole tuber treatment (Kumar et al., 2015). Cutting seed potatoes has offered many advantages to potato production, such as reducing cost by maximizing seed usage per acreage, offering uniformity in seed size. However, cutting seed potatoes found also negative effects including delayed emergence, low sprout vigor and number because of low food reserve, intensive labor requirement, potential for transmission of plant pathogens, and higher risk for seed tuber decay after planting (Hirpa et al., 2010).

\section{Conclusion}

Overall, our data showed that planting whole seed and pre-germinated potatoes contributed to a higher yield than planting cut seeds. Seed piece size and seed pregermination are an important management tool to achieve specific marketing requirement. These results demonstrate advantages of whole and pre-germinated seeds are less sensitive to pathogens and small tuber yield production. Because of the dangers of spreading virus diseases in the cutting operation, the use of Florice variety tuber cutting for seed production is problematical even if the economy of seed cost by using cut seed is not negligible for small producers in developing countries.

\section{COMPETING INTERESTS}

The authors declare that they have no competing interests.

\section{AUTHORS' CONTRIBUTIONS}

PD contributed to the definition of experimental protocols, field data collection, statistical data analysis and article writing. ESS contributed to the definition of experimental protocols, statistical analysis of data and the writing of the article. MD contributed to the definition of the experimental protocols and the writing of the article. BL contributed to the definition of the experimental protocols and the writing of the article KD contributed to the coordination of activities, the definition of experimental protocols, statistical data analysis and manuscript correction.

\section{ACKNOWLEDGEMENTS}

We thank E. SARR, MM. FALL (Agence National d'Insertion pour le Développement Agricole), and N. Guèye for technical assistance.

\section{REFERENCES}

Adhikari RC. 2005. Performance of different size true potato seed seedling tubers at Khumaltar. Nepal Agric. Res. J., 6: 2834. DOI: 10.3126/narj.v6i0.3341. 
Arsenault WJ, Christie BR. 2004. Effect of whole seed tuber size and pre-plant storage conditions on yield and tuber size distribution of Russet Burbank. Am. J. Potato Res., 81: 371-376. DOI: 10.1007/BF02870197.

Cromme N, Prakash AB, Lutaladio N, Ezeta F. 2010. Strengthening potato value chains: technical and policy options for developing countries. Food and Agriculture Organization of the United Nations (FAO).

Engels C, Bedewy RE, Sattelmacher B. 1993. Effects of weight and planting density of tubers derived from true potato seed on growth and yield of potato crops in Egypt. 2. Tuber yield and tuber size. Field Crops Res., 35(3): 159-170. DOI: 10.1007/s12230-013-9317-0.

Arioglu H. 2009. Effects of seed size and inrow spacing on growth and yield of early potato in a Mediterranean-type environment in Turkey. African journal of agricultural research, 4(5): 535-541. DOI: 10.1007/fs 12450-015-9164-21.

Hirpa A, Meuwissen MPM, Tesfaye A, Lommen WJM, Oude Lansink A, Tsegaye A, Struik PC. 2010. Analysis of seed potato systems in Ethiopia. American Journal of Potato Research, 87(6): 537-552. DOI: 10.1007/s12230010-9164-1.

Kabir M, Alam M, Hossain M. 2004. Yield performance of whole-tuber and cutpiece planting of potato. Trop Sci., 44:16-19. DOI: 10.1002/ts.124.

Kawakami J, Iwama K, Hasegawa $\mathrm{T}$, Jitsuyama Y. 2003. Growth and yield of potato plants grown from micro tubers in fields. Am. J. Potato Res., 80: 371-378. DOI: $10.1007 / \mathrm{BF} 02854248$.

Khurana SC, Pandita ML. 1982. Effect of spacing and seed size on growth and yield of total and seed size tubers in potato. J. Indian Potato Assoc., 9: 74-78. DOI: $10.1017 / \mathrm{S} 0021859600086202$.

Knowles NR, Knowles LO. 2006. Manipulating stem number, tuber set, and yield relationships for Northern- and
Southern-grown potato seed lots. Crop Sci., 46: 284-296. DOI: 10.2135/cropsci2005.05-0078.

Kumar P, Kumar R, Kumar A. 2015. Effects of seed cutting and treatment methods of potato on yield, quality and profitability of French fry variety Kufri Frysona. Ann. Agric. Res., 36: 269-274. DOI: 10.1017/S0021859600086202.

Masarirambi MT, Mandisodza FC, Mashingaidze AB, Bhebhe E. 2012. Influence of plant population and seed tuber size on growth and yield components of potato (Solanum tuberosum). Int. J. Agric. Biol., 14(7): 545-549. DOI: 10.1007/BF02854248.

Nelson DC, Thoreson MC. 1982. Effect of seed tuber and seed piece size on growth and incidence of hollow heart in Norgold Russet potatoes. Am. Potato J., 59: 367373. DOI: $10.1017 / \mathrm{S} 0021859600062651$

Nepal S, McIntosh CS, Thornton MK. 2016. Manipulation of physiological seed age of Russet Burbank and Ranger Russet Potatoes - Economic Evaluation. Am. J. Potato Res., 93: 590-601. DOI: 10.1007/s12230-016-9539-z.

Nolte P, Bertram M, Bateman M, McIntosh CS. 2003. Comparative effects of cut and treated seed tubers vs untreated whole seed tubers on seed decay, Rhizoctonia stem canker, growth, and yield of Russet Burbank Potatoes. Am. J. Potato Res., 80: $1-8$. DOI: $10.1007 /$ BF02854551.

R. Core Team. 2015. A language and environment for statistical computing. R Foundation for Statistical Computing, Vienna, Austria.

Strange P, Blackmore K. 1990. Effect of whole seed tubers, cut seed and within row spacing on potato (cv. Sebago) tuber yield. Aust. J. Exp. Agric., 30: 427. DOI: 10.1071/EA9900427

Webster BJ, Chen Y, Gevens AJ. 2018. Impact of seed cutting and seed-borne inoculum on daughter tuber common scab and plant growth. Am. J. Potato Res., 95: 191-198. DOI: 10.1007/s12230-017-9626-9. 